\title{
VER, OUVIR, INTERPRETAR: a propósito dos \\ Sete contra Tebas de Ésquilo
}

Jacyntho Lins Brandão

(FALE-UFMG)

Résumé

Ce travall a pour but d'analyser les relations entre la mise-en-scone et le discours dans le Sept contre Thebes d'Eschyle. On y étudie les données visuelles et auditives en rapport avec le discours. en soulignant leur valeur dans la construction. du texte dramatique, du spetacte of du destin traglque d'Étóocle. 
Os Sete contra Tebas costumam ser considerados, por grande parte da crtica, como um dos melhores momentos do teatro de Ésquilo. Conforme o ponto de vista de Kitto, a peça seria o representante mais bem acabado da por ele chamada "tragédia antiga", correspondendo ao que o Édipo Rei de Sófocles é para a "tragédia intermédia"1. Isso supbe que, nela, se realiza de forma exemplar uma certa concepçăo da tragédia, a "tragédia de uma personagem", sendo Etéocles "o primeiro homem do palco europeu" (1972:106). Ora, a avaliaçăo de Kitto, colocada na dependência de uma certa tipologia, desvela o impasse que, para além da mera constatação do que há de positivo nos Seto, torna a peça de diffcil fruiçăo para um leitor modemo ${ }^{2}$ : apenas se admite sua alta qualidade no contexto de uma tipologia que, embora năo seja cronológica, náo deixa de ser marcada por uma intençăo evolutiva ${ }^{3}$ que repete, em outros termos, o ponto de vista aristotélico de que cabe a Ésquilo uma etapa na evoluçăo da tragédia, por ter ele elevado de um para dois o número de atores, diminuldo a importância do coro $\theta$ feito do diálogo protagonista (Postica, 1449 a). De outra forma, a mesma constataçăo da importância de Ésquilo nessa "evoluçăo" repete-se em Murray (1943), que o qualifica de "criador da tragédia", em Lesky (1976) e em outros.

Năo pretendo negar essa posiçăo referencial do drama de Ésquilo no contexto do que poderia to-lo antecedido ou sucedido. Gostaria, no entanto, de tentar uma abordagem dos Sete que, abstraindo de sua localização na história do teatro ático, ou seja, absolutizando a obra no que ela $\theta$ em si mesma, procure aquilatar seus valores do ponto de vista das funçбées poética, estética e comunicativa do próprio texto ${ }^{4}$. Isso supరé que se deva considerar o texto, antes de tudo, segundo sua intencionalidade, isto é, um texto dramático, destinado à representação e não à leitura. Ao contrário de Aristóteles, consideraria arriscado admitir que qualquer obra trágica "pode atingir sua finalidade, como a epopéia, sem recorrer a movimentos, pois uma tragédia, só pela leitura, pode revelar todas as suas qualidades" (Poética, 1462.a). Sem entrar em outros detalhes, é necessário voltar sempre a insistir no ponto já reiteradamente repetido pela teoria do teatro de que o mesmo compreende texto, ator e público, pelo menos da forma como o teatro $\theta$ entendido e praticado no Ocidente, a partir do modo como se instituiu desde séus primórdios na Grécia. Sintomaticamente, o passo citado de Aristóteles ocorre no contexto de critica aos maus atores, tratando de concluir a respeito da superionidade da tragédia sobre a epopéia, pelo discemimento do trabalho do poeta daquele do ator ${ }^{5} . \mathrm{Na}$

1 - A classificaçăo proposta por Kitto inclui quatro tipos: 1) a "tragédla lirica"; 2) a "tragédla antlga"; 3) a "tragédla intermédia"; 4) a "tragédia nova". Tal classificaçáo é de ordem tjpológica e nâo histórico-cronológica.

2 - Murray (1943: 145) reconhece esse fato: "Pocos lectores modernos considerarian Los Siete contra Tebas su drama griego favorito".

3 - Esse sentido é patente inclusive na utilizaçáo dos termos "antiga". "Intermódla" $\theta$ "nova", embora a 'evoluçâo' náo coincida com a cronologia.

4 - Tomo os conceltos e terminologia de Jauss 1977.

5 - “. . . tal censura (de exagero na representaçáo) náo atınge a arte do poeta, mas sím a do ator". Podtica 1462 a (parenteses meus). 
verdade, a distinçăo é apenas formal e felta num contexto marcado, pois logo adiante se admite a superioridade da tragédia justamente "porque contém todos os elementos da epopéia (chega até a servir-se do metro épico), e demais, o que náo é pouco, a melopéia $\theta$ o espetáculo cênico que acrescem a intensidade dos prazeres que the sáo próprios" (Póstica, 1462 a).

Sabe-se que a trilogia em que se inclulam os Sete teria sido muittssimo apreciada em seu tempo. A ela coube o primeiro prémio em $467 \theta$, Segundo Ateneu (21 f), a montagem obteve grande aceitaçăo sobretudo pela atuaçăo do bailarino Telestes que, com sua dança justamente nos Sete, conseguia fazer que o público "visse as coisas que estavam ocorrendo" (cf. Murray 1943: 146; também Silva 1983: 171-172, em especial nota 79). Trata-se, nesse caso, de observação relativa diretamente ao processo dramático: ver, na verdade, é o que há de mais teatral no teatro, lugar onde se vê. $O$ que haveria pois de superior nos Sete poderia ser entendido neste sentido: uma estrutura de tal forma concebida e articulada que tornaria possivel a fruição estética do espetáculo enquanto objeto de visão. A distáncia que pode existir entre a apreciaçáo do leitor modemo e a do espctador antigo, nos termos propostos por Murray, poderia ser detectada a partir da diferença entre kitura do texto e visão do espetáculo. Isso poderia mesmo induzir a crfica que se baseia na leitura a considerar de um ponto de vista equivocado os fatos, admitindo ser inferiores justamente! aquelas obras ern que o espetáculo, deixando de ser o que há de "menos art'stico e menos próprio da poesia" (Poética, 1450 b) na tragédia, participa efetivamente da composição poética, dos efeitos estéticos e da intençăo comunicativa da obra. O espetáculo deixa de ser um dado assessório e prescindir/dele afeta a fruição e compreensão do objeto. Năo se trata de discutir sobre se esse tipo de peça tem mais ou menos valor que outros em que o cará-' ter espetacular é menos importante ${ }^{6}$. Interessa antes constatar que o espetáculo pode ter peso diferente em peças diferentes. Se tendo a concordar que, em peças como o Édipo de Sófocles, o texto (o mito, a "intima conexăo dos fatos") tem enorme relevância sobre o espetáculo, acredito que em peças como os Sete este assume importåncia considerável.

Crendo nisso é que proponho meu ângulo de abordagem do drama esquiliano em pauta: uma avaliaçăo do papel que tem nele o ver, o ouvir $\theta$ o interpretar. Em príncipio, trata-se de algo impossivel de se avaliar, já que náo dispomos de registro do espetáculo, mas apenas desse ponto de partida que é o texto dramático. Como ponto de partida, entretanto, intencionalmente direcionado para a representaçăo, o texto pode fornecer indicaçőes referentes a sua forma plena de realizaçăo, o que Aristóteles já admitia ao afirmar que, no teatro, "o visual se manifesta na leitura e na cena" (Poética, 1462a).DIto de outro modo, com maior abrangéncia, o texto dramático possui "signos do espetá-

6 - Corroborando seu ponto de vista sobre o problema, Aristoteles cita o Édipo de Sofocles: "o mito deve ser composto de tal manelra que, quem ouvir as colsas que vấ acontecendo, alnida que nada veja, só pelos sucessos trema e se apiade, como experímentará quem ouça contar a historila de Édipo. Querer produzir emoçóes unicamente pelo espetáculo é processo alheio d̀ arte e que depende mals da coregla" (Poética 1453 b). 
culb"7 as marcas de teatralidade que confimam a intençáo que regeu sua composiçáo. Essa intençáo, en vista da finalidade do trabaho postico, tem necessariamente conseqüencias para a tessitura da obra, do mesmo modo que, nos poemas homéricos, a finalidade determinada pela destinaçáo oral dos poemas gera uma série de marcas no texto como produto. Se, nesse caso, como pioneiramente demonstrou Parry (1980), a orālidade afeta as técnicas de composiçâo, também no caso do teatro a representaçăo - 0 espetáculo o fazem. Ainda que de modo tragmentário, creio que se pode, a partir do único dado de que dispomos, 0 texto ${ }^{8}$, abordar o aspecto espetacular. Náo apenas pelo interesse de saber más sobre a realizaçáo plena da tragédia ática, mas, sobretudo, na busca de maior compreensắo do próprio texto.

Essa última intençắo é a minha - aplicada aos Sete contra Tebas, pois parece-me que neles, mais que em outras peças; as marcas do espetáculo se fazem notar náo de modo marginal mas integrador. O espetáculo, nesse caso, náo apenas acrescentaria mais prazer à fruiçăo estética, mas, inseparável do texto, é parte integrante das funçס̋es poética $\theta$ comunicativa da obra. $O$ texto é portanto o ponto de partida $\theta 0$ ponto de chegada e năo imagino que possa ser de outra forma, já que é o documento por excelência que possulmos. A questăo coloca-se, na verdade, em orientar de tal modo a leitura que se possa tirar dele o máximo de informaçăo e de sentido.

\section{Ver: 0 áfono discurso}

Julgo que a característica básica dos Sete é pôr sobre a cena uma situaçăo à huis clos. Se coubesse acrescentar um subttulo à peça, elucidativo de seu caráter, sugeriria algo como "a cidade sitiada". Mais ainda: não consideraria nem mesmo o processo de pór a cidade em stio, mas o próprio estado de sftio, uma vez que estamos diante de uma situação estática, que póe a cidade sozinha diante de si mesma. Há um perigo extemo que, contudo, năo se materializa sobre a cena, a não ser através de indfcios que, interpretados, conformam o desenrolar da açăo. De fato, os sinais do que se passa no exterior e conforma o perigo que gera a situaçáo de crise que, por sua vez, instaura a esfera dramática e trágica penetram na cena unicamente através de dois canais sonoros: os ruldos e as falas do mensageiro e do coro, sendo interpretados pelas personagens reclusas na cidade - o coro e Etéocles, om primeiro grau; o público, em segundo grau.

Voltemos ao ponto de partida: théatron $\theta$ lugar em que se vé. Existe uma cena em que se materializam as coisas $\theta$ para a qual se constrói o discurso dramático. Tudo, no teatro, visa ao visual, deve ser transposto para uma esfera visual. O que năo signifi-

7 - "De fato, os signos do espetáculo que, nas peças em geral, encontramos no texto secundário ou sub-texto, na tragédia grega sấo expressos pelo texto princlpal, isto 6 , pelo texto pronunciado" (Malhadas 1987: 33-34).

8 - Eventualmente podemos dispor de reglstros visuais de cenas do teatro antigo ou de cenas pintadas inspiradas na mise-en-scone do teatro. Sáo contudo dados esparsos, de difill interpretaçáo. 
ca, por outro lado, que possa ou deva ser simplesmente visual, mas também o visual mediatlzado pelo auditivo, entendido como o que se costuma chamar de "efelto sonoro" ou como a fala articulada, o discurso. Retomando a concisáo da fómula aristotéllca, visual $\theta$ auditivo devem estar conjugados, pois no teatro o "visivel está tanto na leltura

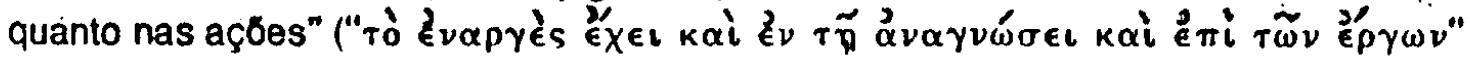
Poética, 1462 a), ou tanto nas palavras (ditas ou escritas) quanto nos fatos representados.

No huis clos da cidade sitiada há, realmente, pouco a representar. Do texto, poderlamos inferir aspectos de mise-en-scène, poucos contudo com segurança, muitos hipotéticos que dependem mais da sensibilidade de uma leitura de cenbgrafo quie de dadós documentalmente verificávels. Assim, do discurso em segunda pessoa introduzldo no primeiro verso pelo vocativo "Kádmou polftar" supbe-se a preseñça de figurantes na cena aos quais Etéocles se dirigiria, bem como as ordens dadäs a partir do verso 30 poderiam corresponder a movimentação desses fiǵurantes, colocando-sê eles a postos na defesa da cidade. Se admitirmos o ponto de vista de Taplin, referendado por Vidal-Naquet ${ }^{9}$, de que não há na tragédia discursos destinados ao público, Etéocles só poderia estar se dirigindo a outras personagens cuja presença o texto năo teria registrado, já que năo lhes cabe fala alguma.

A conclusăo, contudo, não deve ser absoluta, uma vez que possulmos, das peças conservadas em sua integridade e que, portanto, permitem uma análise mais ségură, apenas maís dois exemplos de prólogo em segunda pessoa - no Édipo dé Sófocles e nas Suplicantes de Eurfpides - sendo indubitável apenas no primeiró caso que o ator se dirige a outras personagens em cena, o que se deduz do seguimento da açáo. Por outro lado, há exemplos de prólogos dirigidos náo diretamente, mas em segundo grau, ao público ${ }^{10}$. como nas Bacantes e Feníclas, na Hécuba, no Héracles, nas duas Ifigenia, no Hipólito e na Helena, singularmente todas elas peças de Eurfpldes. Para além do problema do destinatário, o que todas essas falas têm em comum é o fatọ de apreșentar ao público a situaçăo de crise em que tem inf́cio a açăo trágica. Por mais tentadora que seja a possibilidade de deduzir do prólogo dos Sete a evidéncia da presença de figurantes sobre a cena, julgo preferivel ater-me ao único dado incontestável de que o discurso de Etéocles pinta para o público a situaçáo em tomo da qual se desenvolverá a intriga: Tebas sitiada.

É secundário, na verdade, se a fala é "ilustrada" pela representaçáo das açరes que refere, já que o discurso, por si só, é capaz de instaurar a realidade dessas açós. Năo vejo como pudesse ser menos eficaz se Etéocles estlvesse sozinho sobre o palco. Em última instâncla, os figurantes podem estar presentes mas săo dispensávëis. ainda quando se registre em Ésquilo o recurso de colocar em cena personagens mudas, o que me parece náo se aplicar a esse caso, pois o silenclo da Violêncla no Pro-

$9-\mathrm{Ct}$. The Stagecraft of Aeschylus, Oxford, 1977, cltado por VIdal-Naquet 1986: 122.

10 - O endereçamento náo $\theta$ direto por náo ser o texto em segunda pessoa, mas $\theta$ evidente que toda a fala tem sua razáo de ser em vista do público, pols a personagem, multas vezes, se apresenta: eu sou Dioniso (Bacantes): chamam-me Jocasta (Fenfcias); etc. 
meteu prisioneiro é eloqüente por ser rico de significado, o que náo aconteceria aqui. "Ver as coisas acontecendo", no meu modo de entender, diz respeito mais a uma visáo mediatizada pelo discurso que a qualquer tipo de realismo.

Ainda outras hipóteses que depreendem açסes do texto padecem da mesma incerteza. Penso nas sugestóes de que os sete guerreiros tebanos que deverăo opor-se aos sete inimigos eståo em cena, no momento em que săo nomeados por Etéocles, 0 que considero muito improvável (ao contrário do que supóe Kitto 1972: 209), ou de que o diálogo de Etéocles com o coro, a partir do verso 677, seja escandido pelo amamento do mesmo como hoplita (ct. Schadewaldt, Die Woffnung des Eteokles, apud VidalNaquet 1986: 120), o que produziria um belo efeito em termos de marcação de cena, mas cujas evidéncias nos faltam ${ }^{11}$. Mais seguro parece fazer depreender o sistema de fazer ver as coisas da atividade daquela personagem que, na peça, tem como função ver $\theta$ fazer ver. o espião. Sem dúvida, é através dele que os reclusos na cidade sitiada podem ver o que se passa extra-muros. É através dele que o próprio estado de sfítio penetra na cidade e mesmo, em outra escala, no teatro.

Desde 0 inf́cio cabe ao espião introduzir o dado primordial da peça: os sete inimigos que atacarão as sete portas. Significativamente sua primeira fala se abre com a explicitaçăo de seu próprio estatuto - aquele que vê e que traz evidéncias - de que depende a autoridade do que lhe cumpre realizar no contexto da ação:

$$
\begin{aligned}
& \text { " }
\end{aligned}
$$

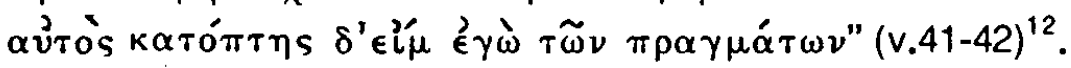

Da açáo do Katóptes ${ }^{13}$ à do phéron saphe $e^{14}$ conforma-se um clrculo de transmissão visual, efetivada não diretamente, mas pela intermediação do discurso. É desse modo, e apenas desse modo, que os sete guerreiros inimigos ganham a cena, bem como é pelo discurso de Etéocles que os seis campeðes tebanos o fazem. Ou seja: a presentificaçăo de realidades concretamente ausentes que o mensageiro proporciona a Etéocles, Etécies proporciona ao público ao nomear e descrever os seis guerreiros tebanos. É a funçăo do Katóptes phéron saphê que Etéocles repete, fazendo, ele também, ver as coisas ao público.

Ainda o coro participa dessa função. Suas primeiras palavras fazem referéncia à cena grandiosa $\theta$ temivel dos cavaleiros que fluem contra a cidade, ao po que se eleva;

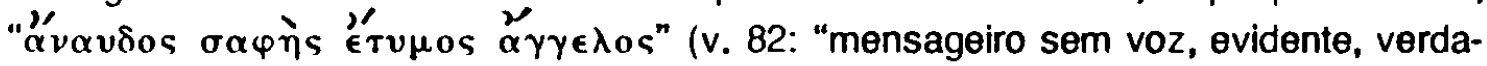

11 - Oưo indfcio, mas de pouca relevância para este estudo, diz respeito à presença na cena de estátuas dos deuses, como poderia depreender dos v. 94-95.

12 - "chego evidéncias de lá, do exército, trazendo e espiáo eu próprio sou dos fatos." (Na traduçấ das citaçбes gregas, opto por me ater o mais literalmente possivel ao original).

13 - O termo define bem o estatuto da personagem: a intençấo de sublinhá-lo fica evidente pela êntase obtda com o uso de autóse egá

14 - Saphés tem evidentemente una carga visual a partir de seu sentido primeiro: "claro". 
deiro" $)^{15}$. Através do discurso impóe-se a evidéncia que, sem palavras, os indícios apontam. Assim como o mensageiro, na funçăo que lhe $\theta$ própria, faz ver, traz evidências, os indicios tamberm fazem ver ao coro o perigo que se aproxima e este, transpondo o visto para o nivel discursivo, faz ver o mesmo ao público: seja a "onda de homens de capacetes ondulantes" (v.113), seja "a multidao de escudos brancos" (v. 90-91) ou o stio da cidade (v.287-300) e mesmo, projetando-se sobre o futuro, o aspecto da cidade conquistada pelo inimigo $(v .321-344)^{16}$. No universo visual (visivel, evidente: saphes) que tal discurso instaura, exige-se apenas que se veja o se que se evidencia. Fato sublinhado na súplica dirigida aos deuses, que pede (ordenando no imperativo):

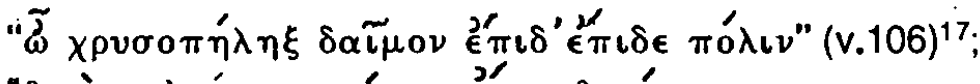

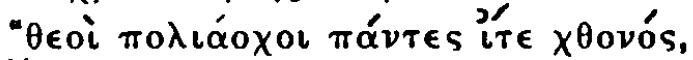

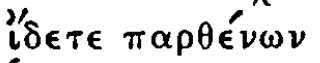

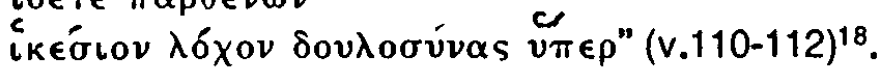

\section{Ouvir: a fala dos ruidos nos ruldos da fala}

Do interior da cidade sitiada não é entretanto ao visível que cabe papel principal, a náo ser em segundo grau, como vimos. De fato, no huis clos que o estado de sftio supōe, a angústia impõe-se justamente pela carência de visăo direta e não mediatizada do que se passa no exterior, geradora de incerteza e de medo. $\hat{E}$ ao medo que se refe-

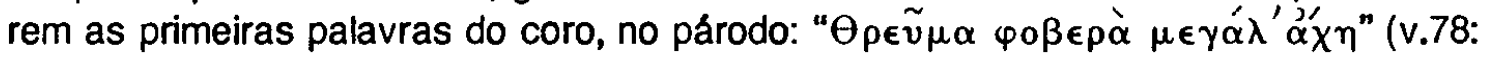
"'Grito de medo e de grande dor" ${ }^{19}$. Embora os discursos precedentes de Etéocles e do mensageiro tenham exposto a situação, com o canto turbulento e angustiado do coro é que, de fato, cresce seu impacto - em outros termos, materializa-se sobre a cena aquilo que a peça visa a mostrar. Essa materialização depende assim menos do que se realiza por ações e mais do que se diz (dizer é também um modo de agir no teatro, ou o modo de agir por exceléncia), na dança enlouquecida das mulheres tebanas. Se é verdade que através da dança do bailarino Telestes é que o público lograva "ver as coisas que estavam ocorrendo", fica claro que esse ver tem uma amplitude maior e que se inclui nele a mediação do discurso verbal, que orienta e dá sentido à própria dança.

Há ainda outro aspecto. A angústia que toma conta do coro depende das informaçóes que o mesmo pode decodificar do que se passa fora da cidade. De um lado, há

15 - A ordem em que os adjetivos aparecem é bastante significativa: diferentementre do espiắo, a poeira é sem voz; mas nem por isso menos verdadeira.

16 - Ainda em outras ocasióes o coro descreve fatos que se passam sobre a cena, com toda probabilidade, como a entrada do mensageiro e Etéocles que para junto dele acorre, nos v. 369-374. Em principio, essa funçăo comum do coro (e mesmo de outras personagens no teatro grego) náo é diferente da que venho analisando. Apenas se dá ela, nos Seta de torma mais ampla e em grau mais complexo.

17 - "O nume de capacete de ouro, olha, olha a cldade".

18 - "deuses que têm a cidade, todos, vinde! vede das virgens súpllce batalhâo contsa a escravidåo!"

19 - Sobre a questáo especfica da angústia e do medo no teatro de Ésqullo, pode-se consultar Romilly 1971, onde se fazem consideraçoes também a propósito dos Seta. 
- que se sabe através do mensageiro e que $\theta$ do conhecimento tanto do coro quanto do público. De outro lado, há os dados que o coro, ele mesmo, pode perceber $\theta$ interpretar, em conjunto com o público: Iniclalmente, um dado vlsual, a poeira aclma referida; mas logo a seguir, com grande força, uma detalhada sequéncia de dados auditivos, denuncladora do exército que se aproxima $\theta$ assedia as portas da cidad $\theta^{20}$.

A importåncla desses últimos tem sido realçada pela crítica, que geralmente concorda em atribuir-lhès o papel de destaque na mise-n-scene (Kitto 1972: 241; Romily 1971: 17-18, em que opరe a Imaginaçăo; Murray 1943: 149-150). Nẩo seria absurdo admitir essa hipótese, embora a própria fala do coro, sozinha, pudesse provocar o mesmo efeito ${ }^{21}$. De qualquer forma, também nesse caso temos um processo de cornunicaçăo mediatizado, já que o coro transmite o que ouve, com o mensageiro transmite o que vê . O próprio canto do coro, turbulento, poderia por si dramatizar o impacto sonoro.

Toda sua fala é singularmente marcada no nivel do estrato fônico, sobretudo nos trechos alusivos aos ruldos percebidos (ktypoi). Assim, nos versos 83-84, que descrevem o estrépito das armaduras $\theta$ dos cascos dos cavalo ${ }^{22}$, encontra-se uma seqũêncla de quatro palavras, que ocupam boa parte dos dois versos, constituldas quase que exclusivamente de sons labials $\theta$ dentais attemados, sugerindo um efeito que, foneticamente, corresponderia a algo como pt (imitaçăo do som provocado pelos cascos ou pelàs armas que se chocam?):

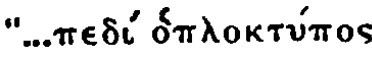

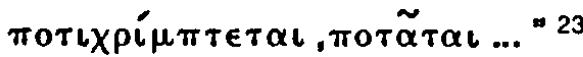

20 - Romilly (1971: 17, nota 1) enumera a seqüência desses dados que têm influência direta no estado de ânimo do coro: a poeira apenas, o barulho dos cascos (v.83), os clamores (v.89), o barulho dos escudos (v.100), o dos carros (v.151) e das pedras contra os muros (v. 158).

21 - O argumento de Murray (1943: 149) de que seria "fatal" que ao grito "de uma mulher" (sic) no verso 100 ("ouvis ou năo ouvis o choque dos escudos?") náo acompanhasse o ruldo correspondente náo mé parece decisivo. Pelo contrário, a forma como a pergunta é feita - ouvis ou năo ouvis? - parece antes sugerir que os ruldos referidos, se de fato percutidos, năo deveriam ser muito nitidos.

22 - "E toma os campos de minha terra o tragor dos cascos:

apresssa-se, voa e ribomba..." Romilly (1971: 17) entende hoplóktypos como "fracas des sabots": etimologicamente, ambàs as leituras seriam justificáveis, o que torna o termo mais rico do ponto de vista que aqqui interessa.

23 - Há notável regulânidade na attermancia de labiais e dentais surdas, com apenas uma ocorréncia dé sonora (d), além de duas guturais também sürdas: $\mathrm{p} / \mathrm{d} / \mathrm{p} / \mathrm{k} / \mathrm{t} / \mathrm{p} / \mathrm{p} / \mathrm{k} /(\mathrm{mp}) / \mathrm{t} / \mathrm{p} / \mathrm{tV}$. Existe uma ơdém relativa nessa sucessáo, que poderia ser assim representada:

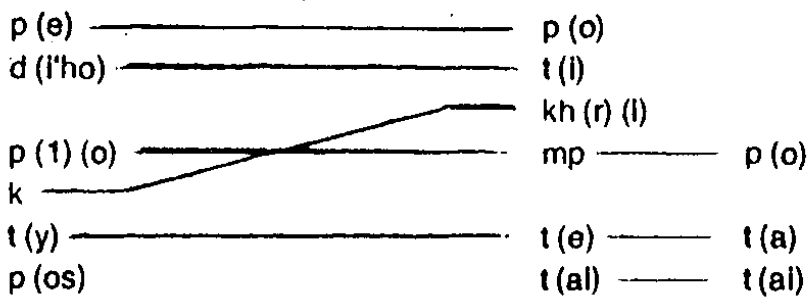

Note-se a ocorrencla paralela do grupo octustva mais vibrante (plo/khn), alóm da correspondencla marcada em -mptotalpotatai. 
O mesmo acontece no verse 100, que se refere o ruldo dos escudos.

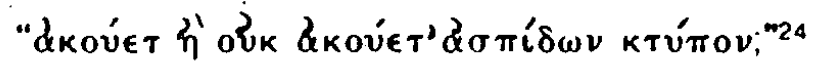

centrando-se o efeito na concentraçăo de consoantes surdas oclusivas (que a gramáttca grega trata sugestivamente de explosivas), cuja tonica corresponderia à seqüência kt presente tanto em akoúte (ouvis) quanto em Ktypon (estrépido) ${ }^{25}$.

Fixemo-nos neste ponto por um momento: de um lado há ruldos; de outro o ouvir. Por mais que se entulhasse a cena de efeitos sonoros, estes apenas teriam sentido na medida em que fośsem ouvidos corretamente. O mero fato de se ouvir náo significa grande coisa - épreciso saber, num caso, que se trata do choque dos cascos ou das armaduras; em outro, de escudos; ainda das pedras, dos carros, etc. Ora, apenas o coro pode ouvir $e_{\text {; }}$ em segunda instância, fazer o púublico ouvir. Dal ser irrelevante se os ruldos se produziam concretamente $\theta$ de que natureza eram. O importante é que. em qualquer caso, se o coro năo mediatiza sua produçăo, representando-os (o que, em certa medida, faz concretamente, através, das ressonâncias fonicamente obtidas), pelo menos os ecoa em seu discurso e, a partir disso, faz ouvir o que se passa. Como acima observei ser imperioso ver, segundo as súplicas dirigidas pelo coro aos deuses, $\theta$ igualmente imperioso ouvir.

$$
\begin{aligned}
& \text { “k } \lambda \tilde{v} \theta \iota \Delta\left\llcorner{ }^{\prime} \theta \epsilon \nu\right.
\end{aligned}
$$

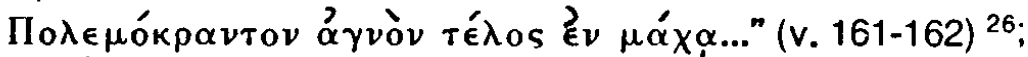

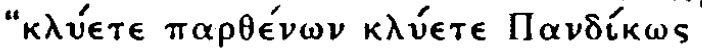

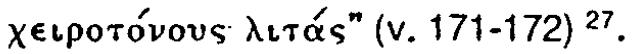

Poder-se-ia argumentar que estes versos se referem não ao ouvir ruldos bélicos que atomentam o coro, mas às súplicas que seu tormento o leva a dirigir aos deuses. A observaçăo é exata $\theta$ dá margem a que se possa discutir com mais detalhes o que se pode chamar de estrato sonoro da peça: de um lado existem sons materiais Inarticulados; de outro o som da fala humana. Ambos estáo em estreita relaçăo e ambos se somam para produzir o efeito trágico, para fazer ver a cidade sitiada.

De uma parte, a fala humana, no ritual do pânico, imita a sonoridade confusa que percebe fora da cidade, atravess das aliteraçð̋es que dominam todo o primeiro canto do

24 - "ouvis ou náo ouvis o fragor dos escudos?"

25 - Ocorre apenas uma consoante sonora (d), em aspldon. De novo se pode observar alguma regularidade:

$$
\text { kI k ik } p(d) \text { ki } p \text {. }
$$

Abstraindo da única sonora, terlamos uma seqüencia bastante regular $\mathbf{k t}$ alternando com outros sons surdos isolados. Ainda o verso 151 apresenta ressonáncla notável, baseada na seqüencla de la-

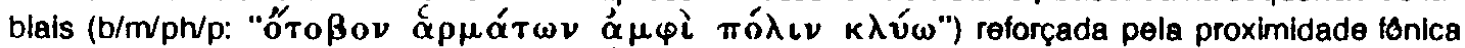
entre póline pótnl que aparece no verso seguinte (152). De fato, todo discurso do coro está repleto de efeltos sonoros no nivel dos significantes, năo obtidos de modo gratuito mas em correlaçấo com os significados (o verso 151 descreve o ruldo dos carros em torno da cidade).

26 - "ouve, de Zeus

titbltro segrado do fim da guerra ..."

27 "ouvi as virgens, ouvi plenamente

as preces de maços expuiden." 
coro. O coro fala uma linguagem apenas em parte humana, em que o significante invade e seqüestra esferas que deveriam pertencer exclusivarnente ao significado. Em outros termos, o significante deixa de ser apenas instrumento do espirto, cresce em autonomia, sublinhando justamente o que tem de materlal, $\theta$ pode ter mais significado que o proprio significado. Trata-se de um embrutecimento da linguagem, o que lembra a acusaçăo de Etéocles contra o coro, ao observar que, com sua dança, semeia entre os cidadâos "âpsykhon káken" (v. 192). Ora, âpsykhos significa 'sem coragem', "tímido', como em geral se traduz o termo nessa passagem ${ }^{28}$, sentido derivado da idéia literal de 'privádo de psykhe' ('sem vida', 'sem ânimo') ${ }^{29}$ - mas, lido na plenitude etimologica, pode significar ainda 'sem alma' (enquanto psykhé se opoe a soma, corpo ou cadáver) ou 'sem inteligéncia' (entendida a psykhé como sede dessa faculdade ${ }^{30}$ ). Além pois de timidez medrosa', a expressấo poderia dar a entender uma 'má disposição privada de espirito (ou de inteligência)'. E não é essa privação de espirito, essa mesccla inumana da fala com a sonoridade desarticulada das coisas que caracterizaria de modo marcante e particular o canto coral em queståo? ${ }^{31}$

Por outro lado, os ruldos falam apenas através do coro. Falam ao coro que, os ecoando, fala por eles. Toda a larga reprimenda de Etéocles contra as mulheres baseia-se, enfim, nesta ordem: escutai a voz dos ruldos mas sem demonstrar. Ou seja: ouvi, mas năo ecoeis; ouvi, mas năo faleis:

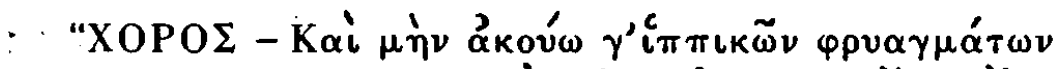

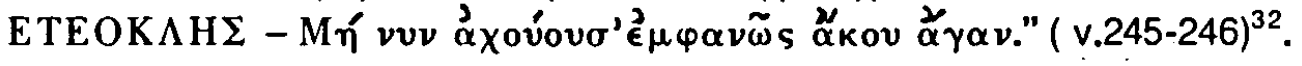

Etéocles desautoriza e probe essa fala de mulheres que ecoa sons inumanos para declarar-se o único intérprete (cf. v. 248) ${ }^{33}$, prescrevendo-thes o tipo de discurso que devem assumir: ouvir o próprio discurso de Etéocles e acompanhá-lo (ecoâ-lo?) com o ololygmós, conforme o costume grego $(v .267-269)^{34}$. Năo fazer isso, significa colaborar com o inimigo, enfraquecer uma cidade que fala a voz da Grécia ("pólin ... Helládos phthóggon khéousan" - literalmer:te, cidade que versa o som da Grécia v. 71-73), conforme a definiçăo dada em passagem anterior pelo próprio Etéocles.

28 - Mazon (in Eschylle 1953:117) traduz "áspykhon káden" por "Iácheté peureuse". Os sentidos referidos, alếm de nessa passagem de Ésquilo, sáo atestados também em Aristóteles $\theta$ Xenofonte (Cineg, 3, 2,), conforme anotam Liddel-Scott e Rocci (s.v.).

29 - Cf., por exemplo, Euripides, Hipolito 952 (em que se opoe animal a vegetal): também registrado em Arqunoco, Simónides, Platáo, etc.

.30 - Esse sentido de psykhé é registrado em Herodoto 5, 124: "psykhén ouk ákros".

31 - Et́focles acusa ainda o coro, no verso 186, de lançar gritos que sáo "misémata sophronon", objeto de odio para os sensatos (etimologicamente, para os que tém mente sadia).

32 - "Coro - Sem dúvida ouço bem dos cavalos o relinchar".

"Etłocles - Ouvindo agora náo demonstres claramente ouvir".

33 - Significativamente a primeira investida de Etéocles contra as mulheres (v. 182-202) termina com a questăo "Ekousas e ouk ékousas, e kouphei légo?". que ecoa a própria fala do coro no verso 100: Sobrepondo-se ao coro e aos rufdos que este imita, é como se Eléocles quisesse marcar que se "impóe também a "tala" turbulenta $\theta$ inumana que veni do exterior.

34 - Sobre a importancla desse grito ritual e sobre seu significado nesse contexto, na distinçáo entre o teminino e o mascullno, ver Vidal-Naquet 1986: 125. 
Também o coro sublinhara anteriormente a vergonha de ser submetida Tebas a um "heterophónoi strator' (v. 170), passagem diffil de se interpretar se tivermos presente que os atacantes sáo, eles também, gregos. Mas náo se poderia lembrar que a única voz do inimigo presente na cena, sem mediaçáo, é aquela constitulda pelo estrépito inarticulado das coisas com que o coro dialoga?

A fala do coro, entregando-se ao medo, embrutecendo a linguagem, fazendo-se ápsykhon, reduplica, dentro da cidade, a fala do inimigo. Aos ruldos exteriores do exército (co)respondem os ruldos emitidos pelas mulheres no interior. Barrado pelas $\pi$ :uralhas, o inimigo já penetrou portanto, de um certo modo, na cidade, espalhando pánico entre seus habitantes. Mais ainda, encontrou neles (nas mulheres do coro) seu principal aliado (cf. v. 193-194). Nesse contexto, ganha novo significado a observaçăo misógina de Etéocles de que as coisas do exterior dizem respeito ao homem e a mulher nåo deve se manifestar.

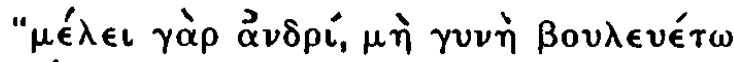
$\tau^{\prime} \alpha \omega \theta \in \nu^{\prime \prime}\left(\right.$ v. 200-201) ${ }^{35}$.

Mais que simplesmente repetir um lugar comum, em que táxothen signifique 'as coisas fora de casa', a observação poderia aplicar-se à cidade sitiada, referindo-se o termo ao exterior da própria cidade, onde se encontra 0 inimigo estrangeiro ${ }^{36}$. Às mulheres cabe "ficar dentro" (endon ousa - v. 201), o que nesse caso não significa voltar para dentro de casa, mas cessar de ouvir, ecoar e dialogar com os ruldos que invadem a cidade a partir do exterior.

A divisão de funçőes entre homens e mulheres e sua oposição é que dá lugar assim à tensão dramática que faz caminhar a açáo. Como bem observa Reinhardt (1972:75-76), drama significa, nessa época, menos uma açăo progressiva que um complexo de relaçס̃es e de tensర̃es ${ }^{3:}$. Essa tensáo constrói-se justamente pelas diferentes leituras que Etéocles e o coro fazem da situação. De um lado, o protagonista quer afastar os indlcios de perigo, quer calá-los pelo autodomínio, pelo domínio das outras pessoas e dos fatos; de outro, as mulheres deixam-se dominar pelos indlcios, representando o que eles sugerem a sua angústia, deixando-se dominar por sua linguagem e repetindo-a. O canto de 287 a 374 é um magistral exemplo de como, a partir dos dados auditivos que penetram na cidade, o coro pode representar visualmente o stio, a tomada da cidade $\theta$ o destino de seus habitantes. A partir dessa atividade interpretativa é que se logra fazer ver o que acontece. Ao contránio de Etéocles, que dá pouca importáncia aos indicios auditivos, que os ouve sem demonstrar recusando-se a decodificá-los, o coro, no envolvimento elevado a grau máximo pelo pavor, năo só os ouve

35. "pois interessam ao homem, a mulher nâo o queira. as coisas de fora."

36 O termo Exothen aplicado ao 'exterior', pode também abranger a idéia de 'estrangeiro'.

37 A observaçáo diz respeito ao Prometeu pristoneira, em que se contrapoe o destino masculino do protagonista ao destino teminino de lo. 
como os ve: "ktypon dédorka" ("vi o barulho" - v. 103), afirma fiteralmente, aliando a seguir o dado auditivo ao vlsual: "pátagos oukh hends dorós" ("o fragor de náo uma única lança" - v. 103) . Ver ruldos, de fato, pode ser entendido como a príncipal funçåo do coro no contexto da peça.

Assim se retorna ao problema da mise-en-scène, pois sem a atividade clarividente do coro o recurso dos ruldos seria inócuo. É preciso que eles sejam decodificados através da fala que os transpoe para a esfera visual. Auditivo e visual, na verdade, se fundem no canto ruidoso, como canto $\theta$ dança se associam no desempenho do coro. O texto que pereniza um discurso voltado para essa finalidade náo passa de um espetáculo malor, ainda que seja marcado pela intençăo espetacular. Ouvindo, falando, cantando $e$ dançando $e$ que 0 coro logra fazer ver as coisas acontecendo de modo sinestésico, o que seria característica distintiva do teatro. Como se pode ver ruldos, também se pode ouvir visóes, o que, afinal, é o que faz o público ao ouvir as descriçסes do coro $\theta$, repetindo o que faz o próprio coro, ao representar mentalmente as cenas que ouve ${ }^{38}$. Ouvir $\theta$ ver, saber ver a partir do que se ouve - isso é o que se exige. Quebram-se os limites entre os diferentes canais de percepçåo na experiência plena da representaçăo. Como se pede aos deuses, esses espectadores privilegiados da açăo trágica, seu público por excelência, que vejam a cidade (v. 106: 110-112) e ouçam suas súplicas (v. 160-165), significativamente também se pede que ouçam a "prece de braços erguidos" (kheirotónous litás - v. 172).

\section{Interpretar: a hermenêutica dos signos}

Se as consideraçס̋es até aqui feitas têm algum valor, devem servir como instrumento para uma abordagem da figura central da peça, Etéocles, e do que nele há de trágico. Com razáo se afirma que os Sete såo a tragédia de um homem só. Baste lembrar que em Etéocles é que se cumpre o fim trágico, atravês do aniquilamento. Tebas se salva - a intriga da cidade sitiada chega a bom termo, a peripécia se dá da infelicidade para a felicidade. Etéocles se perde - $\theta$ o espectador se dá conta de que, afinal, quem se encontrava sitiado era o heról. $O$ que provoca sua queda e faz com que 0 mesmo herói que salva a cidade inteira náo logre salvar-se com ela?

Para responder a tal pergunta seria necessário partir do pressuposto de que houve um erro da parte de Etéocles - que venha a configurar sua hamartia, nos termos do cenceito aristotélico - caso contrario seu estatuto de herói trágico sofreria prejuizo, pois o fracasso, sendo totalmente gratuito, deixaria de ter sentido. No contexto de uma ação que caminha com base na leitura de indícios, o erro de Etéocles deve ser procurado nc modo como efetiva ele essa leitura, ou seja, estaria menos numa falha de

38 - A importância das narrativas na tragédia é realçada por (iregorio (1967:6 ss.) com relaçáo ao papel do mensageiro, que exigia inclusive maior perf́la da parte do ator (ct. Plutarco. Lys $2,3,4$ ) para transmitir ao público o impacto dos latos narrados. Nessa linha e que considero o papel do coro nos Seta o que a tradiça conservada por Ateneu parece contimar. 
caráter ou na força de um destino inelutável que na forma como o herói logra interpretar os dados que the săo postos adiante pela própria situaçăo. O modo como faz isso revela, sem dúvida, seu caráter e seu destino, mas o ponto de partida $\theta$ a açáo que, para usar a formula em tudo exata de VidarNaquet (1986:130). "é um apelo constante à interpretação, a um jogo interpretativo", nos mais diversos graus, envolvendo as personagens, o público $\theta$ os leitores de outras épocas. Como protagonista cabe a Etéocles ser a peça central desse jogo de que depende o destino da cldade e do próprio herol.

Etéocles năo se encontra sozinho: ele conta com os olhos $\theta$ os ouvidos do mensageiro, que até certo ponto age como seu duplo; do coro, que o duplifica igualmente, mas em sentido contrário; $\theta$, de um modo menos evidente mas essencial, dos adivinhos. Ao mesmo tempo, Etéocles encontra-se absolutamente só: recebendo através desses canais os dados da situaçăo, cabe-lhe, $\theta$ apenas a ele, ler os fatos, interpretálos $\theta$ atacá-los de modo conveniente. Missão que reconhece como sua $\theta$ que assume de imediato na qualidade solitária de

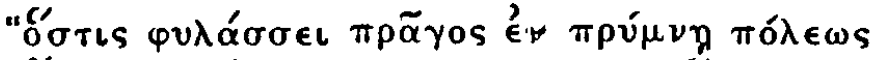

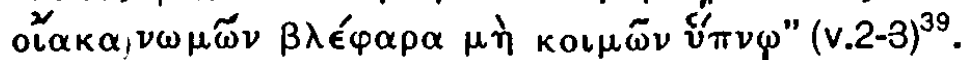

Sua função $\ell$ a do oiakonómos, do timoneiro que não só maneja o timão, mas ainda o dispensa, dirige, governa e, num sentido mais amplo, considera no esp/rito. Assumindo a condiçăo de chefe polttico - e esquecendo, de modo fatal, por exemplo, sua condição de filho de Édipo sobre o qual pesa uma maldiçăo - Etéocles sabe que a salvaçăo da cidade depende dele e que sua glória pessoal depende do que lograr fazer pela cidade (cf. v. 4-9), sem pór em causa o problema de sua própria salvação. Unindo seu destino ao de Tebas, divide também com Tebas a circunstância de estar sitiado e não poder conhecer diretamente os perigos que o ameaçam. Sitiado, o heroi necessita de interlocutores que the transmitam os sinais da crise a serem decifrados por sua perfcia hermenéutica, submetida ela mesma a teste pelos próprios sinais revelam e ocultam.

O primeiro sinal parte do adivinho (provavelmente Tirésias) referido no verso 24 um sinal que marca o infcio da açáo (o nyn da cena dramática) e a impulsiona:

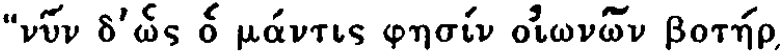

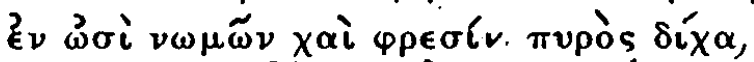

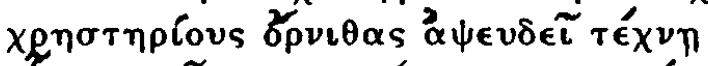

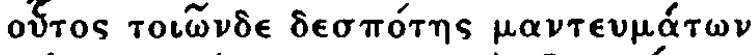

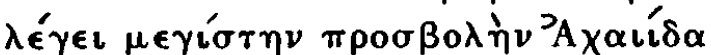

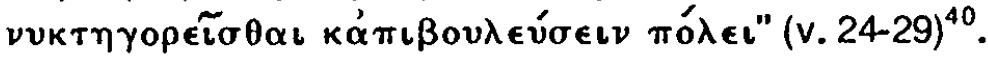

39 - "quem vigla os négocios na proa da cldade, o tlmáo manejando, as pálpebras náo descansando em sonio."

40 - "e agora, como o adlvinho diz, de pássaros pastor, nas orelhas manejando e nas entranhas, sem fogo, oraculares aves com náo mentirosa arte - este senhor de tals presságios diz um grande ataque aqueu à nolte decldir-se e tramar-se contra a cidade." 
Ao referir assim as palavras do adivinho, o próprio Etéocles introduz na açăo outro discurso diferente do seu e que o informa. Fica claro tratar-se de um discurso autorizado: como Etécles, tamberm o adivinho 6 despótes; como a Etéccles, tamberm the cabe a açáo de nomáein ${ }^{41}$. É significativo que o mesmo verbo seja usado com referéncia às duas personagens (v. 3 para Etéocles; v. 25 para Tíresias), fazendo corresponder ao "nomáein o tumáo da cidade" relativo a Etéocles, o "nomáein com ouvidos e entranhas" do adivinho. Ao mesmo tempo que os aproxima, a mesma açăo os distingue, delimitando a competéncia de cada um, mas sobretudo estabelecendo que a Etéocles cabe a olakonomfa, mas năo o que poderfamos chamar analogicamente de "otonomia" $\theta$ "frenonomia", as quais definem a competéncia do adivinho. O primeiro maneja a cidade mas nåo os ouvidos e o esplrito, isto $\theta$, náo está apto para ouvir $\theta$ intrepretar. Justamente o que se exige dele nessa hora. Mas é cedo ainda para tirar qualquer conclusáo.

O segundo sinal vem através do mensageiro, os olhos com que Etéocles perscruta o que acontece além dos muros que o cercam. Tem-se observado com freqüência que o mensageiro não constitui de fato um deuteragonista, uma vez que náo se coloca como antagonista diante do heró ${ }^{42}$. A chave de sua funçăo, com efeito, explicitase nos primeiros versos de sua fala ( $v .40-41)$, como já se observou acima: ver as coisas $\theta$ trazer evidências. De sua ação depende que o herói permaneça incólume:

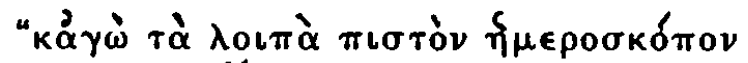

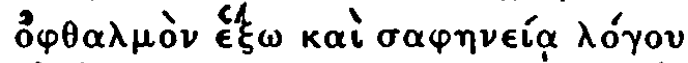

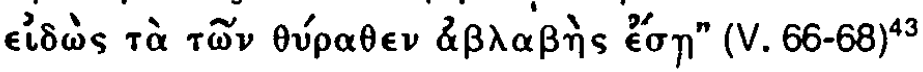

Constró-se assim um esquema que passa pelos olhos fidedignos e vigilantes do mensageiro e por seu discurso que informa o herbi e o impele a agir conforme a oportunidade ("kal tónde kairôn hóstis ókiston labe" - v. 65). Do mesmo modo que Etéocles é incapaz de ouvir e interpretar como o adivinho, $\varepsilon$ incapaz de ver sem o mensagei-

41 - Nomáein é termo quase intraduzfvel na amplitude de seu sentido que comporta três esferas básicas: 1) dividir, distribuir, dispensar, 2) mover, agitar, manejar, govemar, dirigir (como no verso 3); 3) revolver no espifito, observar, considerar (como no verso 25).

42 - “...Etócle n'aura pas d'interlocuter cibyen, à moins qu'on ne tienne le messager, que n'est pas un personage tragique, pour un tel intertocuteur. Mais son rôle est purement fonctionnel." (VidalNaquet 1986: 122-123). Sobre a funçâo do mensageiro na tragédia pode-se consultar Gregorio 1967: 61-62 em especial, em que aponta inovaçoes na relaçáo tradicional do mensageiro com o coro detectadas justamente nos Sete (na última aggella que relata o fim dos dois irmáos).

43 - "e eu, de resto, como fiel sentinela o olho manterel e, pela evidéncia do discurso sabedor das coisas do inimigo, incólume permanecerás."

Deve-se sublinhar a importancia do visual, marcada: 1) pela referencia explicita ao olho - fiel sentinela; 2) pelo uso do termo saphénela: e 3) pela carga visual que o termo eldos guarda, enquanto pertelto de ver' (o que tornarla licito traduzir o trecho como:

"... ө. pela evidencia do discurso

tendo visto as colsas do inimigo..."). Uma outra observaçâo diz respeito ao termo thyrathen, que quer dizer inimigo, mas que literalmente significa 'além das portas', 'extra-portas' (ou extra-muros). Ensalando uma nova traduçáo, mals radical na apreensáo do sentido literal enriquecedor.

“...e, pela evidéncia do discurso

tendo vistọ as coisas dos (que estâo) além (das) portas..." 
ro. Em niveis diferentes, tanto o discurso de um quanto o de outro revelam o mesmo fato: prepara-se um grande ataque, colsa que, por si so, Etécles náo saberia. A ele, na condiçăo de rel, cabe tomar as decisరos pertinentes a partir das informaçסos que recebe.

O terceiro sinal $\theta$ dado pelo coro que, de forma ebqüente e provocante, traz 0 exterior para dentro da cidade, simula o embate e a derrota. Na verdade, o coro age como verdadeiro antagonista do heró, tanto enquanto é capaz de ver, ouvir e interpretar, utilizando uma hermenéutica diferente da de Etécles (que poderfamos chamar de hermenêutica do pânico), quanto porque representa, dentro da cidade, o perigo que o principe procura evitar ${ }^{44}$. Já observel como este desautoriza o discurso do coro, sobrepondo a ele seu próprio discurso. Na condiçåo de antagonista, contudo, o coro é a única entidade em cena capaz de agir sobre o herol. Ainda que aparentemente se deixe dominar, é sob sua pressăo que Etéocles toma a resoluçăo de designar seis guerreiros dos melhores para defender as seis portas ameaçadas, cuidando ele próprio da sétima (v. 282-284),

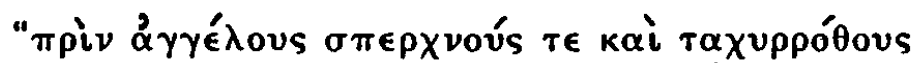

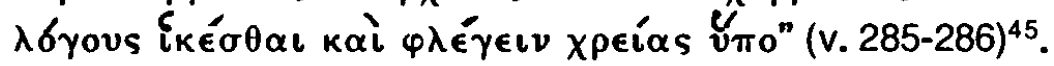

O que se faz evidente nessa passagem, que coroa o processo iniciado com as palavras do adivinho e completado com as do mensageiro e do coro, é que Etéocles quer adiantar-se a novas palavras - antes que novos mensageiros e novas palavras venham: mensageiros impetuosos e ligeiros (sperkhnous) e palavras impetuosas e de ligeiro estrépito (takhyrróthous). Os adjetivos, que podem ser sinónimos em parte, parecem apontar com segurança para os desempenhos anteriores do mensageiro e do coro, para a fala precipitada de um e para o canto ruidoso de outro. Ambos, na verdade, preparam a escolha do herói. Tomando sua decisăo, contudo, E téocles visa menos a cumprir seu papel que controlar seus intertocutores. Ao invés de, na esfera do kairós, buscar mais indicios que informem uma decisăo madura, precipita-se ${ }^{46}$.

Pretensăo vă, pois tem início novo processo que, ao inverso, repete o primeiro: o coro, declarando-se incapaz de conter o medo, a angústla $\theta$ o terror (v. 287-289), entrega-se a novo canto ruidoso que termina apenas com a marcha precipltada do espiáo

44 - "La cité, disons-le dans un premler temps, se rouve prise entre deux dangers, un péril extérieur et celul de la subversion téminlne". (Vidal-Naquet 1986: 123).

45 - "antes de mensageiros impetuosos bem como estrephosos discursos chegarem $\theta$ inflamarem por força."

46 - Julgo que, para essa precipitaça, contibul decislvamente o coro. Ele é que força Etbocles, ao espalhar o pânico pela cidade. Do ponto de vista de Exocles o coro distingue-se claramente do mensageiro, pois enquanto o discurso do segundo vtsa garantir que o heról permaneça ablabes, como observel acima, o do primeiro biaben tithel, segundo as palavras do proprio rei (v. 201). 
que, como da vez anterior, traz novidades (néan phérol - v. 369-371) ( $^{7}$. O próprio Etéocles é descrito em afobada corrida na direçăo do esplăo, movido pelo desejo de informar-se do "artfkolton aggélou logou" (oportuno/ bem ajustado discurso do mensageiro - v. 372-374): dessa feita, a detalhada descriçáo dos sete inimigos que atacam as sete portas, sem dúvida o momento culminante da peça, para o qual tudo converge.

Toda a fala do mensageiro está repleta de sinais (sémata) que se oferecern à interpretaçăo. Parece-me que Vidal-Naquet (1986:132) sallenta bem este aspecto, chamando a atençáo para à predominância de elementos visuais, compostos de " objetos fabricados, de objetos falantes, de objetos significantes, a um só tempo enquanto presságio e enquanto obras de arte". Nấ é necessário repassar aqui toda a série de discursos em que se emitem os sinais aos quais Etécles procura responder, guiado por certo critério exegético. Baste recordar que o caráter de cada inimigo desvela-se petos semata inscritos em cada escudo, do que, em certa medida, Etécles descura. Com efeito, declara ele, abrindo sua série de falas neste ponto:

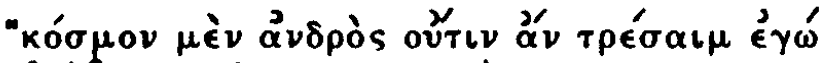

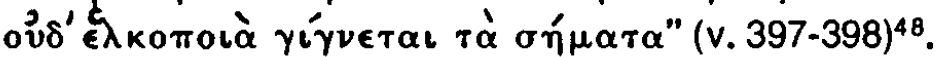

Raciocínio equivocado, pois os sémata são o que se oferece à interpretação, da qual poderia advir a salvaçăo do heró ${ }^{49}$. Perpetua-se assim o erro de cálculo que configura sua hamartía, manifestada antes na precipitaçåo em conter novos anúncios e novas palavras, ou seja, em conter a imupção de novos signos.

De fato, ele tem seis possibilidades de escolha ${ }^{50}$. Cada un dos outros seis guerreiros não passa de delegado ou herói, ao qual cabe, em última instáncia, a defesa da cidade, como ele próprio declarara desde o inicio. Cada um dos sémata, de um certo modo, aponta para Etéocles, provoca-o. Isso devia ser bastante evidente para

47 - O esquema é geometricamente perfeito. Até a revelaçăo final, quaando o espiăo informa que Polinice está na sétima porta, temos, emoldurando a escolha do herói, os discursos do adivinho (incluldo! , no de Etéocles), do mensageiro e do coro, antecedendo-a: do coro, do mensageiro e, referido no discurso deste, a fala do adivinho Anfiaraos, sucedendo a escolha (logo: adivinho/mensageiro/coro/ /ESCOLHA / coro/mensageiro/adivinho).

48 - "nem a aparéncia de homem nenhum temeria eu, nem danosos vêm a ser os signos."

49 - Diferentemente de Etóocies, o mensageiro atribul aos sémata grande importância, esforçando-se em reproduzir com exatidáo o que viu, como promete no inficio de sua fala: "légolm "àn eidos $\theta 0$ (v. 375).

50 - A delicada questáo sobre o momento em que Eţocles toma a decisáo relativa à distribulçăo dos guerreiros tebanos pelas portas tem suscitado multa polémica, sobretudo em vista do uso alternado do futuro, pertello, presente e aoristo em sua fala com o mensageiro. Náo considero entretanto que a presença do pertelto justifique a tese de uma escolha prévia (principalmente se observando que, com relaçăo à terceira porta, usa-se um presente (v. 472) $\theta$ um pertelto (. 473) correlactonados). $O$ argumento decistvo, a meu ver, é que a intençáo última da descriçáo dos inimigos seria emoldurar a escolha do heról Por outro lado, mesmo que houvesse aconteddo uma escolha prévia, ela só se materializa sobre a cena quando explicitada verbalmente - isto é: só entáo passa a existir no universo do drama representado e do público que assisțe ao mesmo. Sobre a queståo, veja-se o recente artigo de Ryzman (1987). 
o público pois, antes de nomeados, os outros seis guerreiros sáo desconhecidos e náo deveriam estar nem mesmo sobre a cena ${ }^{51}$. Sendo assim, em quem o público poderia pensar a cada descrição do mensageiro senăoem Etéocles? Quem opor à fứ a de Tirtdeu, o primeiro adversário, senáo o primeiro dos tebanos? Quem opor a Capaneu, que promete "incendiar a cidade", senáo aquele a quem mais dizem respeito as coisas da cidade? Năo seria Etéocles 0 adversário mais adequado para Etéocles? Contra Tífeu, representado no escudo do gigante Hipomedonte, nảo deveria lutar justamente o rel, ligado de modo estreito a Zeus em virtude da realeza? À esfinge de Partenopeu năo deveria sobrepor-se justamente o filho daquele que lvrara Tebas de seu flagelo? Etécles descura cada um desses indicios (convites, provocaçठes), interpreta-os equivocadamente e busca soluçbes tangenciais que o levam à escolha de outros guerreiros, segundo o critério fatal de

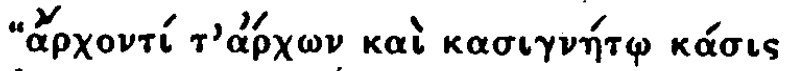

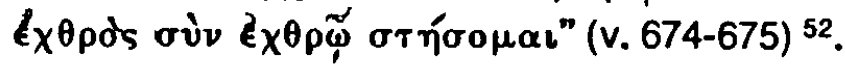

Merece atençăo especial o sexto inimigo o adivinho Anfiaraos. Em primeiro lugar porque leva um escudo sem signo (sema d'ouk epen kykloi - v.591), o que representa uma ruptura no esquema de significação de todo esse trecho, em que os signos visuais săo o elemento básico. Como adivinho, Anfiaraos dispensa os signos visíveis, do modo como o primeiro referido dispensava o fogo, $\theta$ alcança diretamente os fatos, cultivando o interior (phrén). Em outros termos, năo se move na esfera do parecer, mas na esfera do ser, o que se afirma literalmente nos famosos versos:

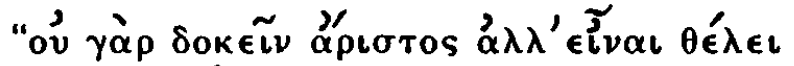

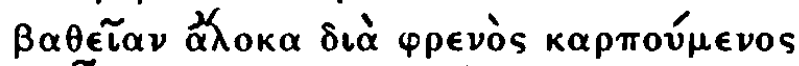

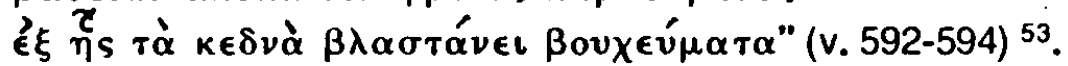

Não o parecer, mas o ser cultivado nas entranhas de onde brotam os nobres designios. É significativo que, no caso dos dois adivinhos haja referéncia â recusa de signos visuais e à preeminéncia do interior. É lgualmente significativo que Etécles se depare, enfim, de novo com um adivinho: este $\theta$ o derradeiro sinal de que a intriga termina onde começou $\theta$ de que desde o principio a hamartla esteve em delxar-se levar por aparenclas. Nesse ponto, de fato, náo existe mais chance de Etéocles escapar ao destino que

51 - Como já observel, nada Impedirla sua presença, mas ela nâo tern sentido para o desenrolar da açăo. Prefiro acreditar que nâo estivessem gratuitamente junto do heról.

52 - "ө a rei, rel, e a irmâo, trmâo, inimigo com inimigo disporel."

O equivoco de tal critêrio é evidente, pols quem săo os rels, os irmấos ê os inimigos envộlvidos na açấo senáo Eţ́ocles e Polinice?

53 - "náo połs parecer excelente, mas ser quer, profundo sulco pelas entranhas cultivando. de que nobres germinam os deslgnos." 
se esconde: na sétima porta Ao contrário de nas situaçoes anteniores, ele náo é o mais Indicado para bater-se contra um adivinho, a partir da diferença estabelecida no comeco entre sua competencia e a do outro adivinho.

2." Por outro lado, Anfiaraos faz ver o que está na iminencla de desvelar-sé. Éle antecipa o aparecimento de polnice - opositor natural de Éteocles segundo o critério que ele propro utiliza cujo nome fora sintomaticamente (intencionalmente?) silenciado ate entáo. Referindo-se a Tideu, que ataca a primería porta e ém segúda a Polinice, Anfiaraos abarca a totalidade da cona descrita peio mensageiro. Eteocies nấ teria mais motivopara ignora o que o espera Mas move-se ainda no campo das aparencias e recusa-se a interpretar o novo dado decisivo que se ine oferécé Como cada ùm dos seis tebanos designados para defender as seís primeiras portas pôde ser cónsiderado

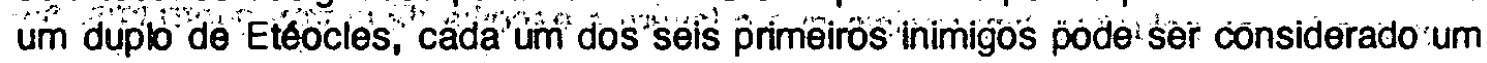
duplo de Polinice. O que Etécles se recusa a ver desde o inicio:e que áiguerra:em curso é a guerra entre ele próprio e o imăo. Na sétima porta çessa a funçáo dos signos, liqüida-se o mundo de aparências que apenàs dùplica simbolicamente o que se esconde por detrás delas: o embate entre ös dois filhós de Édipo.

Năo resta mais que ir ao encontro do que o proprio heroi escolheu para si. A concretude dos fatos impo-se de agora em diante - seja dos fatos passados rélativos a raça de Édipo, que o coro recorda ( $720-791$ ) seja dos presentes que o mensa géro narra: Tebas está salva mas ná seus reis (v $792-819)$ seja principalmenté atránés

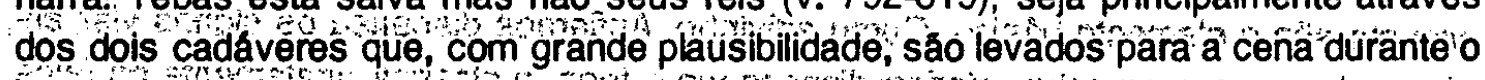

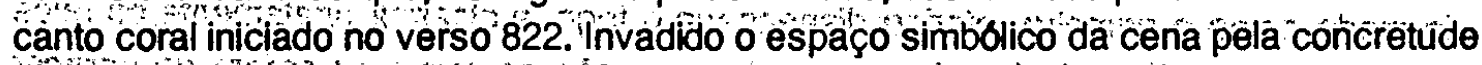
dos dois corpos, qualquer mediaçáo passá a ser desnecesssáná, pós, confome lamenta o coro,

“.... 矛 $\lambda \theta \in \delta^{\prime} \alpha$ -

$\alpha \kappa \tau \dot{\alpha} \pi \hat{\eta} \mu \alpha \tau^{\prime}$ ov $\lambda o^{\prime} \gamma \omega$

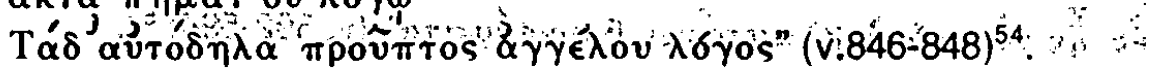

Em certo sentido, ou en seu pleno sentido, esse prooptós logos (discurso manifesto, visivel, posto diante dos ollos), que faz experimentar como ümà so coisa a descriçáo do fim trágico e a visa dós cadáveres, atinge o que se persegula desde o inlcio:o dis-

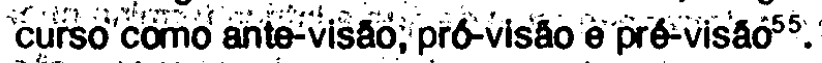

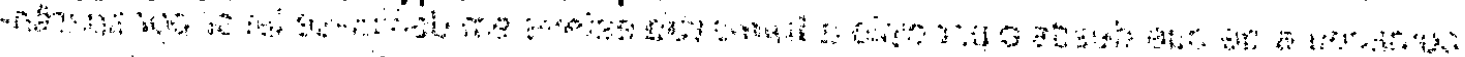

ary a

$\therefore$ a

54 - "...vern a deplo-

rável calamidade nấo em discurso.

Isso é evidente por si, antevisto discurso do mensageiro.

55 - Enquanto proorá (de qué derlva próoptos) pode där a entendèr tanto ver dlante èm sentido espaclal, quanto 'antever', 'prever', na acepcáo temporal que o prefixo émprèsta ao rảdical: :"

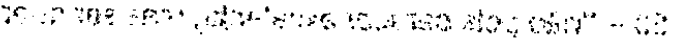

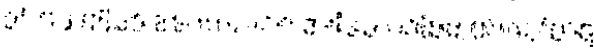

" 
INDICAÇĀO BIBLIOGRÁFICCA

ARISTÓTELES. Poética. Edicción trilingüe por V.G.Yebra. Madrid, 1984. . Poética. Traduçáo de Eudoro de Souza. Porto Alegre, 1966.

ESCHYLE. Les suppliantes. Les Perses. Les Sept contre Thèbes. Promethée enchain6. Texte de P. Mazon. Paris, 1953.

GREGORIO, L. Di. Le scene d'annunzio nella tragedia greca. Milano, 1967.

JAUSS, H.R. Ästhetische Erfahrung und literatische Hermeneutik I. München, 1977.

KITTO, H.D.F. A tragédia grega Coimbra, 1972.

LESKY, A. A tragédia grega São Paulo, 1976.

MALHADAS, D. Hipolito, mito e espetáculo. In DEZOTTI, M.C.C. (org.). Fedra-Hip6lito: a permanência de um mito. Araraquara, 1987.

MURRAY, G. Ésquilo, el creador de la tragedia. Buenos Aires, 1943.

PARRY, M. The Making of Homeric Verse. Ed. by A. Parry. New York, 1980.

REINHARDT, K. Eschyle-Euripide. Paris, 1972.

ROMlLLY, J. De. La crainte et l'angoisse dans le theâtre d'Eschyle. Paris, 1971.

RYZMAN, M. The Departure of the Champions in Aeschylus' 'Septem'. Hermes 115, 1 (1987) : 116-119.

SILVA, M.F.S. Crftica literária na comédia grega: genero dramática Coimbra, 1983.

VIDAL-NAQUET, P. Les boucliers des héros. In VERNANT, J.-P. \& VIDAL-NAQUET, P. Mythe et tragedie - deux. Paris, 1986. 